\title{
WHY THRACIANS WERE THE MOST LONG-LIVED PEOPLE IN ANTIQUITY?
}

\author{
R. Pamukova ${ }^{1}$, E. Radev $^{1}$, M. Vizeva ${ }^{2}$ \\ Department of Preventive Medicine, Faculty of Public Health, Medical University - Sofia, \\ Bulgaria \\ Medical College, "Y. Filaretova", Medical University - Sofia, Bulgaria
}

\begin{abstract}
Thracians were the strongest, the most warlike and the most long-lived among the people of Antiquity, according to historians. On their lands emerged the first European knowledge in medicine, agriculture and livestock breeding. Part of their millennial knowledge has spread around the world contributing to medicine, dietology, phytotherapy, phytochemistry, surgery, hygiene and pharmacognosy. In our analysis we will review medical practices, medicinal plants and foods with long standing tradition and their potential application in complex programs for active longevity.
\end{abstract}

Key words: History of Medicine, Thracians, Longevity, Bulgarian Traditional Medicine, Surgery, Phytotherapy, Mediterranean Diet

\section{INTRODUCTION}

According to the Eurostat Mortality and Life Expectancy Statistics from 2015, Bulgarians rank amongst the populations with the lowest life expectancy rate in the EU - 74.7 years (1).

The Y-Chromosomal Diversity in Modern Bulgarians: New Clues about Their Ancestry, published in 2013, outlines that around 25\% of contemporary Bulgarians descend from tribes inhabiting the Balkan Peninsula since prehistoric times, later becoming part of the Thracian culture. (2)

At the same time, scientific and historic sources suggest that Thracians were the strongest, the most militant and the longestlived among the ancient populations. (3). What was the secret of their longevity?

For the Hellenic tribes, Thrace is the north, which is the world's direction or the source of wisdom. (3) According to archaeological data, the first European civilization arose in Thracian lands around the area of Varna and the Danube River. Later, it gradually expanded on the Balkan Peninsula. (4-7) There, the first societies of farmers and

*Correspondence to: $R$. Pamukova, Sofia, 52

Solunska Str., Mobile: 0988077 29,

r.m.pamukova@gmail.com stockbreeders emerged who introduced the two main ways of food production in Europe. Of particular interest is their way of eating, which is now associated with the Mediterranean diet, well known in medical literature.

The remarkable Thracian material culture includes the creation of the first cities, the emergence of sanitary culture, early writing and medicine.

The medical practice in our lands has a rich history evidenced by archaeological discoveries of complex surgical operations made thousands of years ago. Contemporary pharmacy and medicine use medicinal plants which, according to a number of scientific sources, were used by the Thracians thousands of years ago.

The purpose of this article is to trace the path of millennial medical knowledge in our lands and the Balkan Peninsula to the present day, by analyzing the emergence of agriculture, livestock, medicine and the contribution of this culture to the development of modern European medicine - surgery, phytotherapy, dietology, hygiene and civilized conditions of life, contributing to the active longevity of people. 
BULGARIANS IN THE $21^{\text {st }}$ CENTURY

Eurostat information on life expectancy at birth in the EU-28 countries showed a slight decline in most of them in 2015 (data published in 2017). It was estimated at 80.6 years (0.3 years lower than 2014), reaching 83.3 years for women $(0.3$ years lower than 2014), and 77.9 years $(0.2$ years lower than 2014) for men. The comparative analysis shows that nowadays Bulgarians rank among the shortest living nations in the $28 \mathrm{EU}$ Member States - 74.7 years. Eurostat reports that Bulgarian women have the lowest life expectancy in the EU - 78.2 years, and the Spanish women have the highest life expectancy -85.8 years. (1)

\section{GENETIC ANALYSIS}

In 2013, a study "Y-Chromosomal Diversity in Modern Bulgarians: New Clues about Their Ancestry" was published. This scientific research was conducted by an international team of leading Italian and Bulgarian scientists working at the Department of Medical Genetics, Medical University - Sofia, Department of Biology and Biotechnology, Pavia University, Institute of Experimental Morphology, Pathology and Anthropology with a Museum at the Bulgarian Academy of Sciences and Institute Department of Microbiology "Stefan Angelov" - Bulgarian Academy of Sciences.

To better define the structure and origin of the Bulgarian paternal gene pool, the team has examined the Y-chromosome variation in 808 Bulgarian males. The lineage analysis provided the following interesting results: RL23 is present in Eastern Bulgaria since the post glacial period $(5.2 \%$ of the surveyed men); haplogroup E-V13 has a Mesolithic age in Bulgaria from where it expanded after the arrival of farming (18.1\%); haplogroup JM241 probably reflects the Neolithic westward expansion of farmers from the earliest sites along the Black Sea (3.8\%). (2)
A conclusion was made that around $25 \%$ of modern Bulgarians come from tribes inhabiting the Balkan Peninsula since prehistoric times, which also formed a part of the Thracian culture.

\section{WHY THRACIANS WERE THE LONGEST-LIVED PEOPLE?}

Thracians were the strongest, the most militant, and the longest lived among the populations of the Ancient World. (3). According to the Histories of Herodotus, Book V-3-10, "if one man ruled them, they would have been invincible and far stronger than all other people." It is reported that the Thracians had a very active lifestyle, and that among the gods, they worshiped only Ares (god of war), Dionysus (god of wine) and Artemis (goddess of hunting). (8) Thus, their gods represented their way of life. Historical data and a number of excavations reveal that the Thracians were actively engaged in fishing, e.g. of carp, hunting the following species - lion, lynx, red deer, brown bear, wild bull, etc. $(5,6,8,9)$. Probably, their physical activities, as well as their diet, herbal therapies, surgery, psychotherapy, relatively comfortable lifestyle and sanitary culture have contributed to their longevity.

Nowadays archaeologists find interesting artifacts from this progressive population of long-lived people who have created leading innovations for their time and the first writing in the world.

The golden treasure of Varna, which is the "oldest gold of the world" (Picture 1) dates back to around $5000 \mathrm{BC}$ and it contains more than 3,000 gold objects. It was discovered on the shores of Lake Varna in 1972. It is indisputable among archaeologists and historians that the first European civilization was born around Varna. $(4,5)$

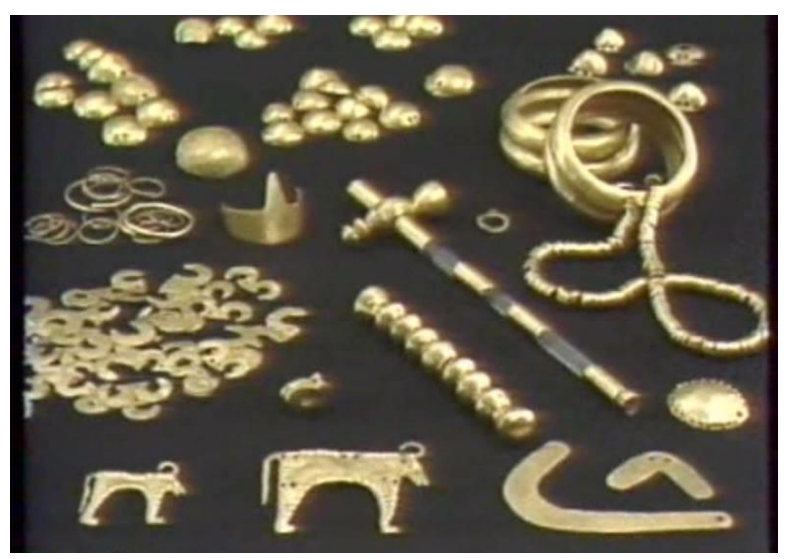

Picture 1. The oldest processed gold in the world, around 5000 BC, Varna Archaeological Museum, Bulgaria (4) 
The Neolithic period on the European continent, when agriculture and the livestock breeding revolution started, first developed around the area of Varna and the River Danube on the Balkan Peninsula. There were appropriate conditions - coastal limes and valleys of larger rivers where there was enough fresh water to satisfy people's living, household and hygiene needs. According to archaeological data, the population domesticated goats and sheep around 10000 BC. In the following millennia they begun to breed horses, rabbits, dogs, birds, incl. home peacocks, etc. The first farmers planted different varieties of wheat (the earliest one cultivated was Einkorn wheat), barley, common vetch, legumes - peas, lentils, garlic, onions, etc. The cereals were harvested with the help of sickles with unsurpassed productivity until the end of the Bronze Age (Karanovo). $(4,7,9)$ During this early period they started to grow the vine (Kazanlak, Village of Chavdar, Sofia, DurankulakBlatnitsa). $(5,7,9)$

The oldest European civilization slowly spread westward to the rest of the continent and eastward to parts of Asia, introducing agriculture, livestock breeding, crafts such as goldsmithing, metalworking and pottery, as well as the oldest writing $(4,6,7)$

The term Danube proto-alphabet signifies letters on clay tiles and writings in caves found during archaeological discoveries from the lower Danube River dating from the Neolithic Age (around 6000 BC). Popular samples are the signs in the Magura cave, the Karanovo print, which according to some studies is an astronomical map, the tiles from Gradeshnica, the tablets from the village of Tataria (Tărtăria - Tăttria), Alba county in present-day Romania and many others. According to K. Kirilov's analysis, 26 of the contemporary Cyrillic alphabet letters have prototypes in Magura (10). It is acknowledged by the international scientific community that the Sumerian cuneiform script came about 2000 years later (around $4000 \mathrm{BC}$ ) and to date the Danube signs are the oldest in the world, known to science. (6, $9,10,11)$

\section{DEVELOPMENT OF MEDICINE}

The first European medicine emerged in this remarkable civilization with interesting culture and first forms of writing. It was perfected from generation to generation and contributed to the active longevity of the Thracians.
Herbalism and surgery have been applied by medical practitioners at that time. The Neolithic settlement at Durankulak Lake belongs to the second half of the 6th millennium BC. From the medicinal plants there were found wormwood (Artemisia absinthium), hops (Humulus lupulus), yarrow (Achillea milefolium), etc. (5) According to the legend, the Thracian Achilles used the white yarrow during the Trojan War to cure bleeding wounds and thus the plant was named after him "Achillea". Nowadays it is applied for similar purposes.

Pollen grains of vine, cornel, etc., were found, as well as remains of fish, fruits, vegetables and others, testifying that the Thracian diet was very similar to the well known in the medical literature Mediterranean diet since prehistoric times and deepest antiquity. Surgery has also been developed. In the ancient necropolis were found skulls of people who were operated by means of a very fine circle. Many trepanned skulls show signs of cranial injuries or neurological diseases, often in the same region of the skull where the trepanation circle was made. $(5,11)$

The Karanovo Settlement Mound is located in the northern part of the Thracian Plain. The excavations reveal cultures dating from the VII ${ }^{\text {th }}$ millennium BC with small interruptions. There was found one of the earliest stamps made of clay with some of the oldest written signs of the Danube protoalphabet dated around $6000 \mathrm{BC}$. There are later mounds in Karanovo proving the continuous millennial development of this interesting culture. There were found 18 surgical instruments with gold and silver inlay (Picture 2), which according to analyses of the leading eye specialist Assoc. Prof. Dr. Koev are only slightly different from the modern ones. Of interest is an instrument that is identical to the Daviel cataract spoon for Ophthalmic Surgery, developed and used in Europe around 15 to 17 centuries later for the first time -- on 8 April 1747 by Louis XV's personal physician Jacques Daviel during his extracapsular cataract extraction. (12)

The first instances of sanitary culture and public health in Europe were also found in the region of Northern Bulgaria. Excavations carried out near Ruse and Razgrad testify that in settlements dated from the Neolithic Period (6 000-4 000 BC) were used waste pits serving also for waste areas. (13) All of the prehistoric and antique settlements were built close to fresh water sources - rivers and lakes 
PAMUKOVA R., et al.

to provide drinking and sanitary water. In the area of Durankulak Lake there is a village with the oldest stone houses in Europe, measuring around 150 to 170 sq.m. (6,000 to 5,000 BC). Archaeological finds reveal the oldest city in Europe in the same geographic area near Provadia, Varna province, in the eastern part of the Danube plain. Historians determine its age between 4700 and 4200 $\mathrm{BC}$ - about 1,500 years before the beginning of the Mycenaean civilization. $(5,6,14)$

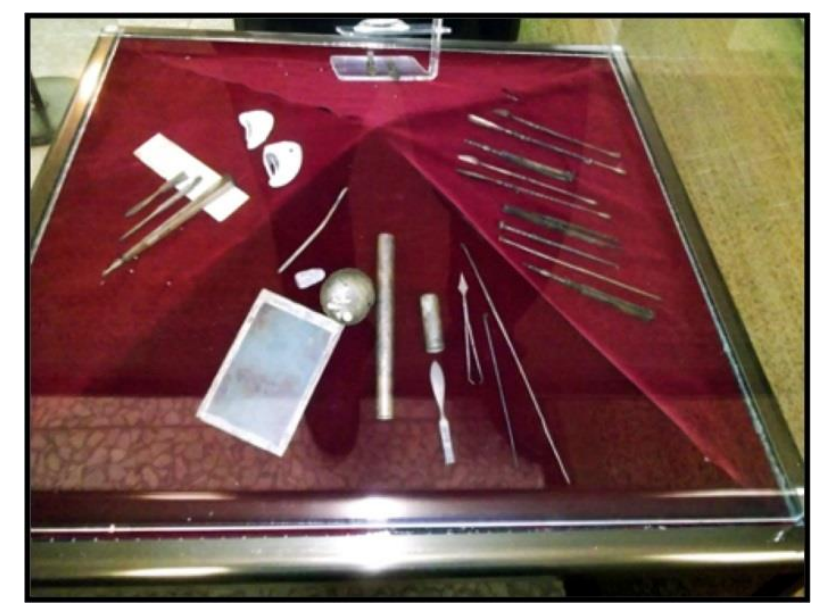

Picture 2. Koev, K, Surgical instruments from the Karanovo Mound, Bulgaria

People have kept their body temperature with leather and woven fabrics weaved on vertical looms, sometimes decorated with gold, beads or molluscs as early as about 10,000 to 6,000 BC. $(4,5,7)$

The Thracian leader, Zalmoxis, was a physician and a priest of the Thracian Getae tribe inhabiting the two banks around the mouth of the Danube River. He played a significant role in the ancient culture and medicine. His methods impressed the legendary fathers of philosophy Socrates and Plato, and the latter studied them in the famous "Charmides" dialogue, written around 380 BC: According to it "it is a mistake for physicians to treat the soul or the body separately. The diseases are treated in a complex method consisting of the use of herbal remedies and healing of the soul. The latter consists of a statement of reasonable principles from which wisdom is born in the soul. Once the soul accepts it, it would be appropriate to give a remedy from plants for the health of the head and the rest of the body." (15) Initial results from studies of long-lived people older than 90 launched in the beginning of 2017 by R. Pamukova outline that wisdom; realism and positivism in addition to natural lifestyle contribute to their long and active lives.

Greeks of the Classical age venerated Orpheus as the greatest of all poets and musicians; it was said that while Hermes had invented the lyre, Orpheus had perfected it. Some sources credit Orpheus with further gifts to mankind: medicine and writing, The Hellenes note that Orpheus, besides the father of Thracian music, poetry and music therapy, he has also given rise to herbal therapy and medicine. The philosopher and rhetorician Alcidamas credits Orpheus with the invention of writing $(3,6)$ The Thracian leader recorded his knowledge of herbalism, medicine, philosophical and religious sciences, as well as his poetry on clay and gold tiles. The existence of "books" of Orpheus has many different sources of evidence. On a bronze mirror from the $\mathrm{V}$ century BC, the legendary Thracian is depicted with a lyre and a basket of scrolls and books. (6) According to Euripides his books were written on the most precious metal of all - gold for its divine and medicinal properties (Picture 3). $(3,4,6)$

The Derveni papyrus, found in Derveni, Macedonia in 1962, contains a philosophical treatise that is an allegorical commentary on an Orphic poem in hexameters, concerning the birth of the gods. Fragments of the poem are quoted making it "the most important new piece of evidence about philosophy and religion to come to light since the Renaissance" (16) The papyrus dates to around 340 BC, making it Europe's oldest surviving manuscript. Plato in his dialogue "The Republic" tells of priests who would offer purifications to the soul using books by Orpheus and his student Musaeus. (15) According to Batacliev (1989) only 363 fragments are left from the enormous work of Orpheus (3). The historian W. Mitford wrote that the very earliest form of a higher and more cohesive ancient religion was manifested in the Orphic poems: Those poems, unquestionably 
of great antiquity are found scattered among the writings of the philosophers and historians [e.g. in the Hymn to Jupiter, quoted by Aristotle in On the World]. The main ideas of the enlightened Thracian are that: "One God once governed the universe. He is the creator and preserver of all things. God being One has

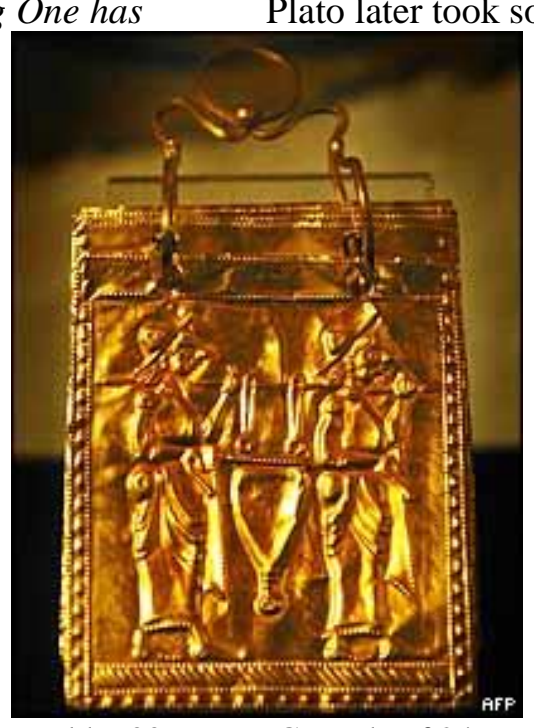

thus received many names, according to the variety of effects of which he is the cause" That purer religion, then according to the undisputable testimony of Herodotus, was brought into Greece by its first inhabitants...from Thrace. Pythagoras and Plato later took some of his ideas. (17)

Picture 3. The oldest book in the world, 600 years BC, made of 24-carat gold, 6 pages, cult to Orpheus (National History Museum, Bulgaria)

Picture 3 shows the oldest book in the world (600 BC) made of 6 pages of 24 karat gold. It is related to the Orpheus cult. The book was discovered around 60 years ago in a tomb uncovered during digging for a canal along the Struma River in southwestern Bulgaria. (6, 18)

Followers, who were devoted to "Orphic way of life" - often practiced music therapy, vegetarianism and used medicinal plants $(3,6$, 17) According to Theophrastus of Eresos Orpheus shared the believe that "the Earth is the prolific parent of every herb, for Earth is the Vesta of God, on whose fertile surface they growg, as on the soft bosom of a mother or a nurse." (6) We learn from Argonautica that he used the "powers" of the following plants were - anise (Pimpinella anisum), lavender (Lavandula spica), paeonia (Paeonia peregrina) among dozens of other. His most famous student in herbal medicine was Linus. (3)

During the millennia of antiquity, knowledge about the effect of medicinal plants has been accumulated, enriched and passed on from one generation to another. Theophrastus of Eresos (III century BC), writes " Enquiry into Plants " (Historia Plantarum), approx. 350$388 \mathrm{BC}$, one of the most important books on botany and medicinal plants in Antiquity. It describes botanical species and their use in medicine in ancient Thrace, alongside these in Ancient Egypt, a proof that in antiquity the knowledge of Thracian medicine was honoured and respected. $(3,14)$ The book is one of the most significant manuals on plant anatomy, tree and plant propagation as well as medicinal uses of plants written in ancient times. Likewise, it was influential in the Renaissance and it was translated and reissued, cited by a number of authors over 2,300 years; most recently in 2012 in the World Vocabulary for Medicinal Plants in 5 volumes $(19,20)$.

"De Materia Medica" by Pedanius Dioscorides (I century), describes dozens of medicinal plants used by the Thracians. That book is the first pharmacopoeia in Europe and the world - a book containing descriptions of plants and the medicines that can be obtained from them. Thus were set the foundations of pharmacy, pharmacology and pharmacognosis. $(19,21,22)$ The medicinal plants cited there used by the Thracians cover the most important areas of medicine gastroenterology, cardiology, pulmonology, nephrology, parasitology, gynaecology, ophthalmology, dermatology and others. (19, $21,22,23,24)$ In contrast to many classical authors, the book by Dioscorides about the application of medicinal plants was not "rediscovered" in the Renaissance, because it was constantly used and never left circulation to present days. In the medieval period it was circulated mainly in Latin, Greek and Arabic. In the Renaissance from 1478 onwards, it was printed in Italian, German, Spanish, French, 
English, etc. and it has been actively used by pharmaceutical and medical professionals even nowadays in the 21 st century $(19,21$,
PAMUKOVA R., et al. 22) The most recent translations are in German - from 2005, English - 2000 and Italian - 2013 (19).

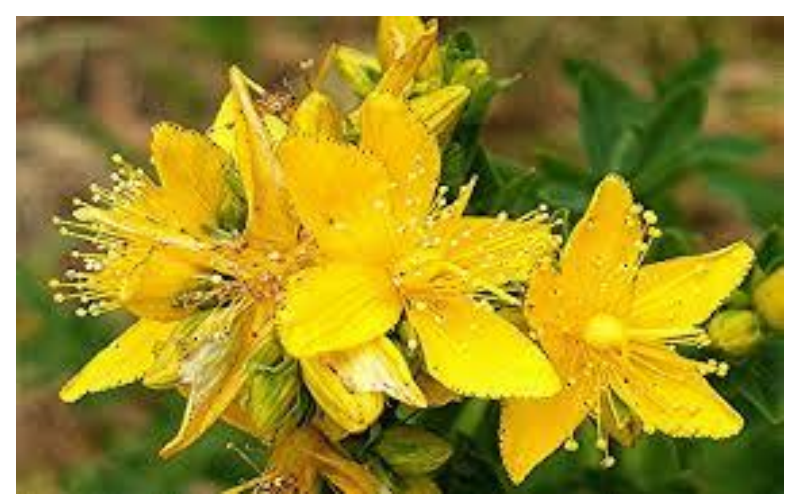

Picture 4. St. John's Wort (Hypericum Perforatum), a medicinal plant used by many long-lived people

Following its long way through the centuries and the millennia, the profound knowledge of ancient Thracians about the effect of certain medicinal plants has spread and entered into the medicine of Europe and the rest of the world. (19) Some of them are used nowadays in medicines and food supplements. For example, St. John's Wort (Hypericum Perforatum) is applied today in medicine and is popular among many long-lived people.

\section{CONTEMPORARY RESEARCH}

The honey and the spices added as flavorings to the food and wine, associated with god Dionysus, contributed to the active longevity of the Thracians.

Epidemiological studies of different populations worldwide prove the protective effect of red wine in cardiovascular diseases. Small amounts (20-30 $\mathrm{ml}$ of concentrated alcohol per day) or a glass of wine reduce the risk of ischemic heart disease. However, higher levels of alcohol increase health risks. $(25,26)$

The traditional Mediterranean diet, rich in fruits, vegetables, moderate use of fish and meat, the limitation of sugar in food and beverages replaced by honey is similar to the Thracian diet, as evidenced by a number of excavations. It contributes to low cardiovascular mortality, decreased prevalence of type 2 diabetes mellitus and low incidence of chronic diseases such as Parkinson's disease, Alzheimer's disease, rheumatoid arthritis, etc. In the medical literature it is associated with a long life. (25, 27, 28)

Most spices used from Thracians to present days are medicinal plants rich in valuable ingredients that have antibacterial and antiviral effect, such as garlic (Allium sativum), anise (Pimpinella anisum), dill (Anethum graveolens), mint (Mintha spicata), etc., supporting digestive and metabolic processes. $(19,21,22,23,24)$

Numerous longevists, as well as doctors, including ancient Thracians and Hypocrates, used the plant St John's wort (Hypericum Perforatum) for treatment of back and joints pain. The plant also has a capillary strengthening and vasotonic effect, which is associated with the combined presence of vitamin $\mathrm{P}$ (rutin) and vitamin $\mathrm{C}$ in its composition. Hypericin tones the nervous system in depressive states, sadness, insomnia, etc. (Weiss, 1974). The stimulation of new epithelial cells formation, the antiinflammatory and spasmolytic effect of St. John's wort are mainly due to flavonoid glycosides. $(22,24)$ Hops (Humulus lupulus), used by our ancestors since around $6,000 \mathrm{BC}$ (excavated in Durankulak), also finds application in geriatrics - it relaxes the nervous system, relieves insomnia, improves digestion, etc. The estrogenic effect of Humulus lupulus is being studied along that of other species. $(5,22,23,24)$

Currently, the in-depth studies of medicinal plants, which are around 300,000 species, continue. (19) Of the 252 medicinal products rated by $\mathrm{WHO}$ as valuable, $11 \%$ are only obtained from plants and contribute to the increased average life expectancy of people nowadays. $(19,29,30)$

\section{CONCLUSIONS}

Scientific sources state that Thracians were the longest-lived people in the ancient times. According to archaeological discoveries, medicine in Bulgaria and the Balkan Peninsula has the longest standing tradition in 
Europe of around 10,000 years. Hence, that rich empirical expertise gives exclusive value to the Bulgarian traditional medicine, which uses complex methods covering mainly dietology, wine therapy, music therapy, psychotherapy and phytotherapy. Their undeniable effect has been proven after many independent studies. Thanks to ancient sources some of the Thracian millennial knowledge of the effects of certain medicinal plants has spread and entered the medicine of Europe and the rest of the world. Some of them are studied and applied in our age.

Initial results from a research carried out by R. Pamukova among contemporary long-lived people aged over 90 suggest that wisdom, realism, hard physical work and positivism contribute to their long life. The majority of longevists surveyed use natural products such as garlic (Allium sativum), honey, drink alcohol in moderate quantities, and many of them collect medicinal plants that can be freely found in nature, which is important due to the unfavorable economic situation of many elderly people. Many of them use St. John's wort (Hypericum perforatum), thyme (Thymus vulgaris), hawthorn (Crategus monogyna) and other plants, traditionally applied by the Thracians.

It would be advantageous to issue an evidence-based medical guide for elderly people and their relatives with practical advice on healthy lifestyle, nutrition, psychotherapy and application of essential medicinal plants. In our days public health systems face many challenges. The above natural, safe and cost effective methods with proven millennial history of use by our ancestors would be beneficial in complex healthcare programs for active longevity.

\section{REFERENCES}

1. Eurostat. Mortality and Life Expectancy Statistics, published in 2017. http://ec.europa.eu/eurostat/statisticsexplai ned/index.php/Mortality_and_life_expecta ncy

2. Karachanak S, Grugni V, Fornarino S, Nesheva D, Al-Zahery N, Battaglia V, et al. Y-Chromosome Diversity in Modern Bulgarians: New Clues about Their Ancestry. PLOS ONE, 06.032013 http://journals.plos.org/plosone/article?id= 10.1371/journal.pone.0056779

3. Kunovski, G., The Healing Tradition of Bulgarians in the Past and Today, Volume 1. ASI Print, Sofia, 2006, p. 89-108

4. Delova, A., The Tharcians' Gold Treasures,
PAMUKOVA R., et al. http://alexandradelova.blogspot.bg/2015/0 3

5. Ismail A., T. Dimov, Archeological Complex at Durankulak Lake - Nature, Ecology, Discoveries. Dobrich Regional History Museum http://www.dobrichmuseum.bg/index.php/ bg/research/archaeology-research/30arheologicheskiyat-kompleksdurankulashko-ezero-priroda-ekologiya-iotkritiya

6. Sachev, E., The Bulgarians are at the Core of Human Civilization. Second Supplementary and Extended Edition, Publishing House "The New Civilization", Sofia, 2017

7. Todorova, H, I. Vajsov. Der kupferzeitliche Schmuck Bulgariens. PBF XX, 6, Stuttgarrt, 2001.

8. Herodotus, History. New Bulgarian University, Sofia, 2010

9. Architecture and Archeology - Settlement and Burial Mounds, Karanovo Settlement Mound

http://www.bgjourney.com/Architecture/m ogili/ html.

10.Kirilov, K. 26 of Our Letters have Prototypes in Magura. Bulgarian National Radio, http://bnr.bg/vidin/post/100683396

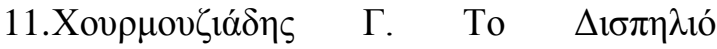

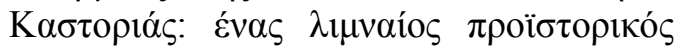

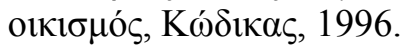

12.Koev, K., Surgical Instruments of the Thracians from the $1^{\text {st }}$ Century, Among Which for Eye Surgery, Similar to the Modern Instruments. Bulgarian Medical Journal, 5, 2011, No 2

13.Apostolov, M. History of Medicine. Medicine and Physical Education, Sofia, 1977.

14.BBC, Europe's 'oldest prehistoric town' unearthed in Bulgaria. BBC News, 31.10.2012

https://www.bbc.com/news/world-europe20156681

15.Plato. Dialogues, Volume 1, Charmides, p. 250-253, Volume 3, The Republic p. 364 c-d. S., Science and Art, 1979

16.Kouremenos, T., GM Parássoglou, K. Tsantsanoglou, The Derveni Papyrus. Edited with Introduction and Commentary. Studi e testi per il "Corpus dei papiri filosofici greci e latini", vol. 13. Florence: Casa Editrice Leo S. Olschki, 2006, Pp. xvi, 310

17.William Mitford, Baron John Mitford Redesdale, John Freeman-Mitford Redesdale (1st baron) Printed for $\mathrm{T}$. Cadell, 1838, Vol. 1 p. 89-96 
18.BBC, Unique book goes on display. BBC News, 26.05.2003 http://news.bbc.co.uk/2/hi/europe/2939362 .stm

19.Pamukova, R., Medicinal Plants Studied at the Dawn of Medicine. Medical Meridians, No. $1 / 2018$, p.44-47

20.Quattrocchi, U., CRC World Dictionary of Medicinal Plants: Common Names, Scientific Names, Eponyms, Synonymus and Ethymology, 5 volumes, 2012, p. 2111

21. Asenov I., S. Nikolov, Benbassat J. Pharmacognosy. Medicine and Physical Education, Sofia 1989, pp 13-433.

22.Dioscoridis, P. De materia medica libri sex. University and Biblioteca Nazionale of Naples, 2013

23.Dimkov, P., Bulgarian Folk Medicine, Natural Treatment and a Natural Way of Life. Publishing House of the Bulgarian Academy of Sciences, Sofia, 1979, item 3, pp 5-22.

24.Pamukov D., H. Achhtardzhiev. Natural Pharmacy. Zemizdat, Sofia, 1989, p. 5296.
PAMUKOVA R., et al.

25.Vodenicharov T., S. Popova, M. Mutafova, E. Shipkovenska. Social Medicine. GorexPress, Sofia, 2013, p. 75-480.

26.German JB, RL Walzem, The Health Benefits of Wine. Annu Rev Nutr. 2000.20, p. 561-93

27.Vizev, K., Biological Age as a MedicalSocial Problem and its Influence on Some Endocrine Factors, A. Angelova-Angela, Sofia, 2010, pp. 9-162

28.Swain, J., Ph. B. McCarron, , E. F. Hamilton et all Characteristics of the Diet Patterns Tested in the Optimal Macronutrient Intake Trial to Prevent Heart Disease (OmniHeart): Options for a Heart-Healthy Diet, J Am Diet Assoc. 2008 Feb; 108(2): 257-265

29. World Health Organisation, Traditional Medicine Strategy, WHO, 2002

30.World Health Organisation, Essential Medicines and Health Products Information Portal, National Policy on Traditional Medicine and Regulation of Herbal Medicines - Report of WHO Global Survey, 2005 http://apps.who.int/medicinedocs/en/d/Js 79 16e/9.4.html 